\title{
Território, territorialização e territorialidade: o uso da música para a compreensão de conceitos geográficos
}

\author{
Territory, territorialization and territoriality: \\ the use of music to understand geographic concepts
}

\author{
Territorio, territorialización y territorialidad: \\ el uso de la música para la comprensión de los conceptos \\ geográficos
}

Lucas Labigalini Fuini

lucasfuini@yahoo.com.br

UNESP - Ourinhos

Resumo: O presente artigo pretende contribuir com o ensino de Geografia, tanto no ensino básico quanto na graduação, através da perspectiva de investigação do conceito de território e suas novas variantes de análise difundidas na Geografia brasileira contemporânea, como as concepções de territorialização, desterritorialização, reterritorialização, territorialidades e microterritorialidades. Nesse sentido, considerase que o recurso textual, em especial as letras da música popular brasileira, pode auxiliar na contextualização e explicação de noções e conceitos fundamentais para a ciência geográfica, como é o caso do território, considerando os aspectos pedagógicos das canções para construir a mediação entre conceitos científicos e conceitos escolares, tarefa fundamental para o ensino de Geografia.

Palavras-chave: Território. (Des/re)territorialização. Territorialidades. Canções.

Resumen: Este artículo tiene por objeto contribuir a la enseñanza de la Geografía tanto a nivel escolar como a nivel de graduación, la investigación desde la perspectiva del concepto de territorio y sus nuevas variantes de análisis difundidos en la Geografía brasileña contemporánea, como los conceptos de territorialización, desterritorialización y reterritorilización, la toma de posesión y la territorialidad y microterritorialidades. En este sentido, se considera que el recurso textual, la música popular brasileña en particular, puede ayudar a contextualizar y explicar los conceptos y las nociones fundamentales de la ciencia geográfica, como la planificación, teniendo en cuenta los aspectos pedagógicos de las canciones para construir mediación entre los conceptos científicos y los conceptos de la escuela, fundamental para la enseñanza de Geografía.

Palabras-clave: Territorio. (De / re) territorialización. Territorialidad. Canciones.

Abstract: This article seeks to contribute to Geography teaching both in schools and at the graduate level. The article discusses research from the perspective of the concept of territory and its variants within contemporary Brazilian Geography, such as the concepts of territorialization, deterritorialization, reterritorialization, territoriality and micro-territorialities. Textual resources, particularly Brazilian popular music, can assist 
in contextualizing and explaining fundamental concepts and notions for geographical science, such as planning, and the pedagogical aspects of songs can be used to build mediation between scientific concepts and school concepts, which are fundamental to the teaching of Geography.

Keywords: Territory. (De/re) territorialization. Territoriality. Song.

\section{INTRODUÇÃO}

O território aparece como um dos conceitos fundamentais da ciência geográfica, constituindo o edifício dessa ciência desde que ela se consolida em termos oficiais e institucionais, a partir do final do século XIX. Sendo conceito, ou seja, uma abstração a designar um conjunto de relações e processos, o território também apresentou, no desenrolar da história do pensamento geográfico, diferentes designações, conforme o contexto histórico ou o referencial filosófico e ideológico a tratá-lo.

Mais recentemente, a ciência geográfica retoma com ímpeto o emprego desse conceito para a análise da realidade socioespacial, ocupando o posto de destaque que no passado, estava associado a outros conceitos e categorias fundamentais, como região, espaço e paisagem. A Geografia brasileira também passou a se situar nesse debate com mais vigor a partir de início dos anos 1990, atendendo ao prenúncio do geógrafo Milton Santos (2002) ao tratar do "retorno do território", ou do território usado, como ele mesmo definia. O "território usado são os objetos e ações, sinônimo de espaço humano e espaço habitado" (SANTOS, 2002, p. 16), onde se encontram as horizontalidades (lugares vizinhos, continuidade territorial, espaço banal) e as verticalidades (pontos distantes uns dos outros ligados por formas de processos sociais, redes).

Sack já afirmava, nos anos de 1980, que a territorialidade humana não se resume à territorialidade biológica dos animais, baseada nas relações instintivas e de poder. A territorialidade humana, segundo o autor, é entendida como uma "estratégia espacial para afetar, influenciar e controlar recursos e pessoas, através do controle de áreas, e como estratégia, pode ser ligada e desligada. Em termos geográficos, ela é um comportamento espacial" (SACK, 1986, p. 3).

Além disso, passam a vigorar também novas leituras de território na atualidade devido aos debates epistemológicos internos à Geografia e ao contexto de mudanças profundas no mundo e nas filosofias interpretativas deste. Passou-se, portanto, a valorizar, conforme aponta Claval (1999), a questão das identidades e das relações personalizadas de indivíduos e grupos com os lugares. Segundo o autor, a erosão de valores tradicionais e a mobilidade mais intensa facilitada pelas comunicações criam situações novas e redefinem a ideia de identidade com os territórios, inclusive da própria relação entre sociedade, Estado e território.

Posteriormente, outros geógrafos se inseriram nesse debate e voltaram seus olhares ao conceito, com especial atenção para as novas qualidades que este assumia com o processo de globalização e mundialização da economia e os movimentos de 
reestruturação produtiva no/do território (CHESNAIS, 1996; CASTELLS, 2003). Assim, aparecem com força as especificidades do território: seu conteúdo, princípio, finalidade e representação, as territorialidades; e sua ação, movimento e processo, as territorializações, desterritorializações e reterritorializações.

Para Boligian e Almeida (2003), os conceitos ou as categorias-chave de cada ciência podem ser empregados como elementos "facilitadores" do processo de aprendizagem, na medida em que passam a nortear os conteúdos escolares, criando condições para que os processos pedagógicos tenham maior sucesso no âmbito da sala de aula. Além disso, esse aprendizado de conceitos, para se tornar mais atraente e significativo ao aluno, pode partir do entendimento das representações sociais dos alunos, propiciando a atividade mental e física dos mesmos em situações de cooperação e interação (CAVALCANTI, 1998).

Mais especificamente, o território pode atuar como um conceito "facilitador" no ensino de Geografia, por entendermos que todos os outros conceitos geográficos (espaço, região, paisagem, lugar) fundamentais estão, de certa forma, e em escalas diferentes, em constante diálogo com o território. Como considera Boligian: "Pela sua abrangência teórica, o conceito de território nos parece ser mais que um conceito-chave da Geografia. Na realidade, o território é, por assim dizer, um metaconceito da ciência geográfica." (BOLIGIAN, 2003, p. 236).

E, adicionalmente, a música - com suas letras - se coloca como instrumento importante e favorável à discussão e reflexão coletiva em sala de aula sobre conceitos da Geografia, estimulando a estruturação de conceitos científicos em conceitos escolares através da observância de dois elementos: cotidiano/vivência do aluno e a relação dialógica professor-aluno. As letras das canções, por seu conteúdo rico, popularidade e atualidade, estimulam o aprendizado de conteúdos geográficos, pois instigam os alunos ao interesse pela descoberta do novo e dão ao professor outros meios para realizar seu papel de intervenção na aprendizagem, problematizando e reconstruindo os conteúdos aprendidos na escola.

\section{OBJETIVOS E JUSTIFICATIVA}

O presente artigo tem como objetivo oferecer sugestões para o desenvolvimento de um raciocínio geográfico (CAVALCANTI, 1998) sobre o conceito de território e suas dinâmicas mais recentes, usando, para isso, letras da música popular brasileira. A desterritorialização, reterritorialização e as territorialidades múltiplas podem ser analisadas com as referências históricas e geográficas que certas canções nos trazem, servindo como recurso discursivo e mediação didática para o trabalho de pesquisa e docência em Geografia.

Busca-se também uma atualização e sistematização sobre as novas tendências da discussão territorial na Geografia brasileira, pautada nas perspectivas de relações de poder (RAFFESTIN, 1993), do território usado (SANTOS, 2002; SANTOS; SILVEIRA, 2010) e do território cultural material-imaterial, simbólico e identitário (SPOSITO, 2004; SAQUET, 2007). Com isto, pretendemos demonstrar que a ciência geográfica e suas pesquisas de 
vanguarda devem ser apropriadas pela escola em seu trabalho educativo e crítico, apresentando as letras de música como mediação no processo de construção de conceitos.

A justificativa para a realização desse estudo decorre do papel chave que o conceito de território exerce nas pesquisas científicas da Geografia brasileira contemporânea. Além disso, ressalta-se aquilo que os Parâmetros Curriculares Nacionais de Geografia (2002) já apontavam ao conferirem aos conceitos, dentre os quais o de território, a condição de eixos estruturantes no ensino-aprendizagem de conteúdos, habilidades e competências. E, por fim, há um reconhecimento atual da importância da música como inspiração para investigações sobre lugares e paisagens, pois aparecem como relatos de cotidianos e eventos socioespaciais (SANTOS, 1996), além de exercerem um papel pedagógico fundamental de estímulo e aproximação dos alunos com os conteúdos escolares e como ferramenta de exercício da criatividade e autonomia (FUINI, 2013).

\section{MATERIAIS E MÉTODOS}

Kong (2009) ressalta que a música pode e deve ser utilizada na análise de paisagens, ambientes e espaços, pois serve como elemento de contextualização para análise de fatos e eventos socioespaciais, além de ter também uma função pedagógica, no ensino de Geografia para crianças e jovens.

O presente artigo propõe, inicialmente, a construção de um breve quadro explicativo sobre conceitos científicos e escolares, com destaque para o conceito de território na Geografia, conforme autores selecionados (RAFFESTIN, 1993; COSTA, 2005; SAQUET, 2007, SANTOS, 1996, 2010).

Posto o contexto teórico do estudo, analisaremos letras de música selecionadas, considerando suas fortes referências geográficas, envolvendo espaços e tempos específicos. As músicas são as seguintes: Saudosa Maloca, de Adoniran Barbosa; Sobradinho, de Luís Carlos Sá e Guttemberg Guarabyra; Aluga-se, de Raul Seixas e Cláudio Azevedo; Disneylândia, da banda Titãs. Analisaremos alguns de seus trechos de forma a incorporar as perspectivas da territorialização, com seus prefixos "des" e "re"; e a ideia de territorialidades, com seus prefixos "des" e "micro".

Durante a análise das letras de música, conforme sua contextualização históricogeográfica, definiremos também as noções de "território político", "território econômico" e "território cultural".

\section{O TERRITÓRIO E SUAS NUANÇAS}

O território é o recorte espacial definido por relações de apropriação, poder e de controle sobre recursos e fluxos baseado em aspectos políticos, econômicos e culturais (HAESBAERT, 2006; SAQUET, 2007; SPOSITO, 2004). O território contém formas diversas de apreensão e de manifestação individual e coletiva de um Estado, grupo cultural, classe social ou atividade econômica. 
Uma das principais associações que a ciência geográfica estabelece é entre o território e o exercício do poder. Para Raffestin (1993), o território é um espaço (ou uma produção a partir do espaço) onde se projetou um trabalho, seja energia e informação, e que revela relações marcadas pelo poder. Andrade (2004) apresenta uma visão de território vinculado ao espaço de exercício de um poder (domínio ou gestão de uma área), tanto do ponto de vista de um poder público-estatal quanto pelo poder das grandes empresas. Moraes (1988; 2002) enfatiza que o território, ou a formação territorial, como prefere, é constituído, ao mesmo tempo, pela dimensão material das formas de apropriação/produção do espaço pelo Estado e pelas atividades produtivas; e pela dimensão imaterial, da construção ideológica e do imaginário territorial referente aos discursos e práticas de identidade nacional e de identidades regionais. O território seria, ao mesmo tempo, uma construção militar, econômica, jurídica e ideológica. Em suma, Moraes (2002) afirma que o território:

[...] pode ser equacionado como uma construção simbólica, vinculado a um imaginário territorial. Contudo, trata-se também de uma materialidade, produzida pela apropriação material de espaços e dominação efetiva destes. Assim, a formação territorial articula uma dialética entre a construção material e a construção simbólica do espaço, que unifica num mesmo movimento processos econômicos, políticos e culturais. $\mathrm{O}$ território material é referência para formas de consciência e representação, cujos discursos retroagem no processo de produção material do espaço, com o imaginário territorial comandando a apropriação e exploração dos lugares. (MORAES, 2002, p. 74).

Haesbaert (2006) destaca que o território pode ser definido em termos políticos, ou político-jurídicos e históricos, referentes à ação do Estado; em termos econômicos, associado à apropriação econômica dos espaços, derivada da divisão territorial do trabalho e da luta de classes; e em termos culturais, identificado com relações simbólicas - individuais ou coletivas - com o espaço.

Considerando a dimensão cultural, Bonnnemaison (2002) caracteriza o território em sua perspectiva humana (além de seus significados biológicos, econômicos, sociais e políticos) como o lugar da mediação entre os homens e sua cultura, nascendo dos pontos e marcas que os homens deixam no solo (geossímbolos, lugar, itinerário, uma extensão, por motivos religiosos, políticos e culturais, que exerce uma dimensão simbólica e de identidade), definindo um meio de vida e o enraizamento de um grupo social.

Assim, o território seria partilhado, em termos de significado, com a ideia de territorialidade. A territorialidade seria a expressão de um comportamento vivido, englobando a relação do território e o espaço estrangeiro, incluindo aquilo que fixa o homem aos lugares e aquilo que os impele para fora do território (entre o fixo e o móvel; entre o que dá segurança e o que projeta a liberdade). Essas questões envolveriam a definição de um espaço cultural:

[...] como espaço geossimbólico, carregado de afetividade e significações: em sua expressão mais forte, torna-se território-santuário, isto é, um espaço de comunhão com um conjunto de signos e valores. A ideia de território fica associada à ideia de conservação cultural. (BONNEMAISON, 2002, p. 111). 
Robert Sack (1986) também se esforçou em apontar para uma definição de território mais ampla que aquela que o reduzia à dimensão espacial do Estado-nação, reforçando seu caráter humano. Em sua perspectiva, a territorialidade nos humanos é algo enraizado social e geograficamente, estando relacionada à maneira com que as pessoas usam o meio e organizam-se no espaço e como dão sentido ao lugar. A territorialidade é um uso sensato do espaço historicamente, sendo o componente geográfico para se entender como a sociedade e espaço estão inter-relacionados.

Aterritorialidade, paraRaffestin(1993),refletea perspectivademultidimensionalidade do vivido territorial por membros de uma coletividade social. São as relações de poder (produtivistas ou existencialistas) que se estabelecem entre atores nas suas relações com a natureza e sociedade. Em suma, a territorialidade é definida como um conjunto de relações que se originam num sistema tridimensional sociedade-espaço-tempo, com o objetivo de se buscar, de forma crescente, autonomia associada aos recursos de um sistema.

Andrade (2004) afirma, por sua vez, que a territorialidade advém da consciência que as pessoas que habitam um território têm de sua participação na formação histórica destes, que se dá de forma subjetiva (consciência de confraternização, de se sentir parte, de integrar-se ao território de um Estado). A territorialidade seria aquilo que se encontra em um território e está sujeito à sua gestão.

A territorialidade pode ser definida também como o próprio conteúdo do território, suas relações sociais cotidianas que dão sentido, valor e função aos objetos espaciais. Essas territorialidades são associadas aos diferentes tipos de usos do território. A desterritorialidade seria, portanto, resultado de um processo de desterritorialização, na perspectiva do desenraizamento dos produtos, capitais, mão de obra e, sobretudo, de grupos étnicos, lealdades ideológicas e movimentos políticos em processos de transferências de fronteiras ou desmantelamento de identidades territoriais. Trata-se de um processo de transferência de fronteiras, raízes, centros decisórios e de pontos de referência nas esferas econômica, política e cultural (IANNI, 1992; apud NEVES, 2002).

Haesbaert (2006) reivindica o uso da noção de multiterritorialidade à dinâmica combinada de múltiplos territórios em termos de justaposição e convivência da diversidade territorial representada pelas dimensões sociais, escalas e dinâmicas. Segundo ele:

Essas dinâmicas se desdobram num continuum que vai do caráter mais concreto ao mais simbólico, sem que um esteja dicotomicamente separado do outro. No caso de um indivíduo ou grupo social mais coeso, podemos dizer que eles constroem seus (multi) territórios integrando, de alguma forma, num mesmo conjunto, sua experiência cultural, econômica e política em relação ao espaço. (HAESBAERT, 2006, p. 341).

Poderíamos tratar então de territorialidade associada a grupos sociais, eventos culturais e religiosos, intervenções públicas, investimentos privados, etc. A territorialidade se expressa em espaços e tempos distintos e, às vezes, simultâneos, como é o caso dos centros urbanos, com as territorialidades do comércio entrecruzadas pelas territorialidades das tribos urbanas, do trânsito, das igrejas, enfim, com a justaposição de territorialidades sagradas e profanas. Até mesmo podemos tratar de territorialidades cíclicas, com o uso de 
espaços urbanos pela atividade empresarial durante o dia e, à noite, pela prostituição e por usuários de drogas, por exemplo (SOUZA, 1999).

Já a territorialização, ou reterritorialização, seria o movimento de se constituir referenciais simbólicos e identitários (materiais e imateriais) junto a um recorte espacial definido, dotando-o de unidade. Poderia ser também chamada de enraizamento territorial, vinculando populações, empresas e instituições de governo ao território. A desterritorialização, em seu oposto, representa a extroversão e desenraizamento de povos, atividades sociais e econômicas e comunidades de seus lugares, correspondendo à perda de identidades e do enraizamento. A reterritorialização, por sua vez, compreende o movimento de reconstrução e retomada de laços de identidade e inserção territorial sob novas bases de qualificação.

Segundo Haesbaert (1999), uma das marcas centrais do movimento de desterritorialização moderno e globalizado seria a produção de aglomerados, símbolos da chamada "desterritorialização extrema" e "precária", que nos trazem a perspectiva de uma massa disfuncional sem identidade e espacialmente definida por um ponto, linha ou superfície.

Haesbaert (2006) e Haesbaert e Ramos (2004) realizam reflexões fundamentais sobre a desterritorialização do capital e da população e cunharam a relação entre redes e aglomerados, dando um enfoque aos conjuntos populacionais em situações de exclusão social e marginalização econômica, os aglomerados de exclusão. Ao sistematizar uma tipologia para aglomerados, aparecem três tipos centrais: aglomerados radicais, marcados pelas condições de vida precárias e extremas, como os refugiados e deslocados em áreas de países pobres; aglomerados tradicionais, vivendo em situações endêmicas de exclusão e fome (ex.: sertão nordestino brasileiro); e os aglomerados transitórios ou conjunturais, geralmente de caráter ilegal ou clandestino e marcados pela violência e medo (ex.: favelas dominadas pelo narcotráfico).

Mais recentemente surge outra linha de análise territorial, também preocupada com os modos de apropriação simbólicos e culturais, definida pelas "microterritorialidades". Segundo Fortuna (2012), a microterritorialidade seria uma modalidade de socialização articulada com valores, subjetividades e afetos, reconhecendo formas de organização social não institucionais e transformações radicais de valores e estilos de vida. A microterritorialidade pode também ser abordada como uma escala interpretativa dos eventos motivadores de ações territoriais, sendo notada de forma mais concreta através dos estilos de vida urbanos e suas manifestações coletivas e individuais. Um exemplo dessa perspectiva seria o trabalho de Turra (2003) sobre o movimento punk em Londrina, conforme o entendimento das representações e apropriações espaciais por um grupo de jovens com identidade cultural e territorial específicas.

A raiz dessa discussão se encontra, segundo Costa (2005), na relação entre território, identidade e cultura incorporada nas microterritorializações urbanas. Considerando que toda identidade envolve territorialização (materialização-objetivação-visibilidade dos atributos e da organização dos grupos sociais em diferentes escalas) - no contexto da cidade atual com sua heterogeneidade social e multiplicidade de centralidades - é possível falar que 
a convivência social e as práticas culturais de certos grupos singularizam determinados espaços, os pequenos lugares, via apropriação e especialização.

Constroem-se, assim, os microterritórios internos, como parques e praças, por determinados atores não convencionais ou formais, como as chamadas tribos urbanas, com manifestações de tolerância positiva com essa prática, quando a microterritorialização urbana é pautada na hibridização cultural, no diálogo, na troca de informações e no conteúdo subjetivo/estético entre estranhos, ou de tolerância negativa, quando envolvem a exclusividade relacional de agregados sociais para proteção de práticas culturais em locais específicos (praças, parques, ruas, shoppings, etc.).

Outra noção da mais profunda relevância na análise geográfico-territorial é a das identidades territoriais. Segundo Chelloti (2010), existe um consenso de que toda identidade é uma construção social e que os diferentes grupos sociais, ao longo do tempo, criaram significados, definindo identidades, sejam elas vinculadas a uma determinada cultura, ideologia, religião, etnia, dentre outras. Além disso, a identidade é construída por subjetividades individuais e coletivas e pode estar relacionada a grupos sociais ou ao pertencimento territorial, construindo a ideia de territorialidade.

Haesbaert (1999) explora o conceito de identidade socioterritorial como sendo um tipo de identidade social (identificação ou reconhecimento das pessoas em relação aos objetos, coisas ou outras pessoas, tendo um forte conteúdo simbólico e histórico) que parte ou transpassa o território, referindo-se, mais especificamente, àquelas que se situam frente a, ou em, um espaço simbólico, social e historicamente produzido, podendo se referir desde ao recorte de paisagem e espaço cotidiano vivido até ao recorte mais amplo de Estado-nação. De forma mais específica, refere-se a um tipo de identidade que envolve uma dimensão histórica de imaginário social, associada ao espaço de referência de memória de um grupo, como alguns monumentos ou lugares históricos.

As identidades territoriais, para Moraes (1988), em complemento, estariam mais associadas a ideologias ou discursos geográficos, tais como: a) aquela que vincula uma visão de espaço/território/lugar à ideia de "caráter", "aptidão" ou "destino" de uma determinada área; b) aquela que coloca as questões sociais como qualidades do espaço (ex: determinismo geográfico); c) ao tipo normativo aplicado ao espaço em diferentes escalas e que se refere aos planos e programas para ordená-lo, destruí-lo ou reconstruí-lo.

Podemos, assim, sintetizar no quadro abaixo (Quadro 1) o conjunto de referências centrais que definem o território na atualidade. 
Quadro 1 - Diversas concepções atuais sobre Território, com suas designações

\begin{tabular}{|c|c|c|}
\hline Conceito & Definição & Exemplos \\
\hline Território & $\begin{array}{l}\text { Recorte espacial definido por relações de poder, controle } \\
\text { e apropriação. Extensão de um poder, associado a limites } \\
\text { e fronteiras. Definido pelos sistemas de engenharia, } \\
\text { normas, instituições e atividades econômicas e sociais, } \\
\text { sinônimo de território usado. }\end{array}$ & $\begin{array}{l}\text { Estado-nação e suas unidades de controle administrativo; } \\
\text { área de operação e controle de uma empresa ou grupo } \\
\text { de empresas; referência para identidade nacional, étnica } \\
\text { ou religiosa. }\end{array}$ \\
\hline Território político & $\begin{array}{l}\text { Normativo, definitivo pelo Estado-nação e instituições } \\
\text { político-administrativas; Remete ao controle de recursos, } \\
\text { fronteiras e de fluxos populacionais. }\end{array}$ & $\begin{array}{l}\text { País, Estado ou Província, município; projetos de } \\
\text { controle estatal, conflitos entre fronteiras, distribuição } \\
\text { de recursos públicos, distribuição geográfica de políticas } \\
\text { e serviços públicos. }\end{array}$ \\
\hline Território econômico & $\begin{array}{l}\text { Incorporado à lógica de ação privada-mercantil, define- } \\
\text { se pelo controle de recursos econômicos (matérias- } \\
\text { primas, terras, força-de-trabalho, tecnologia) e também } \\
\text { é definido pela relação capital-trabalho e luta de classes. } \\
\text { A definição dos territórios econômicos também conta } \\
\text { com a assunção dos Estados através de seu quadro } \\
\text { administrativo e normativo. Envolve a perspectiva da } \\
\text { seletividade territorial da ação do capital. }\end{array}$ & $\begin{array}{l}\text { Ação das empresas em áreas específicas (centros } \\
\text { urbanos, distritos industriais, portos/aeroportos, } \\
\text { tecnopolos), articulando as áreas de produção com as } \\
\text { áreas de distribuição, circulação e consumo; Envolve } \\
\text { formas de recrutamento e de controle da mão de obra, } \\
\text { definindo uma divisão social do trabalho; Depende, para } \\
\text { sua constituição, de externalidades de infraestrutura e } \\
\text { formação/qualificação. }\end{array}$ \\
\hline Território cultural & $\begin{array}{l}\text { Material e imaterial, com conteúdo ideológico e } \\
\text { simbólico, definido pelas relações de apropriação e } \\
\text { representação construídas pela lógica do cotidiano, } \\
\text { tanto pessoal quanto coletivo, criadora de sentimentos } \\
\text { de pertencimento e de identidade com o lugar ou os } \\
\text { lugares. }\end{array}$ & $\begin{array}{l}\text { Pode ser étnica, religiosa, de nacionalidade, familiar, } \\
\text { tribal, comunitária, lingüística etc. Configura-se pela } \\
\text { ação de grupos e indivíduos em recortes espaciais que } \\
\text { inspiram historicamente formas de identidade. }\end{array}$ \\
\hline Territorialização & $\begin{array}{l}\text { Ação, movimento ou processo de construção e criação } \\
\text { de territórios pela apropriação, uso, identificação, } \\
\text { enraizamento com determinadas extensões do espaço } \\
\text { por lógicas políticas, econômicas ou culturais. É também } \\
\text { sinônimo de qualificação ou organização territorial. }\end{array}$ & $\begin{array}{l}\text { Criação de estruturas político-administrativas e projetos } \\
\text { estatais; ação de empresas e grupos de empresas em } \\
\text { áreas mais ou menos planejadas, em centros urbanos } \\
\text { ou em suas periferias; grupos e individuais que passam } \\
\text { a definir um cotidiano e criam um sistema de relações } \\
\text { com um lugar, por força do trabalho, necessidade de } \\
\text { sobrevivência, moradia, da cultura-tradição etc. }\end{array}$ \\
\hline Des-territorialização & $\begin{array}{l}\text { A desterritorialização é o oposto da territorialização } \\
\text { pois envolve o desenraizaimento e a desorganização de } \\
\text { territórios pela saída ou perda de vínculos identitários da } \\
\text { população que constitui um território/territorialidade, } \\
\text { ou pela ação externa de comandos estatais ou } \\
\text { corporativo-empresariais que introjetam novas lógicas de } \\
\text { modernização capitalista e de controle político estranhos } \\
\text { ao território. A globalização, enquanto processo e } \\
\text { discurso do capitalismo financeiro e monopolista, } \\
\text { teria uma lógica intensamente desterritorializadora. } \\
\text { A desterritorialização associada a catástrofes naturais, } \\
\text { guerras e pobreza cria os aglomerados de exclusão. }\end{array}$ & $\begin{array}{l}\text { Migrações por motivos de pobreza, guerras e } \\
\text { perseguições; deslocalização de atividades econômicas } \\
\text { pela busca de redução de custos de produção e atrativos } \\
\text { locacionais (guerra dos lugares); ação das redes } \\
\text { industriais e financeiras, articuladas pelas tecnologias } \\
\text { informacionais, em busca de novas áreas para } \\
\text { investimento, desorganizando as economias domésticas } \\
\text { e impondo novas lógicas de modernização capitalista; } \\
\text { homogeneização cultural e confronto com culturas e } \\
\text { tradições locais e regionais, que atuam como resistências } \\
\text { territoriais. }\end{array}$ \\
\hline Re-territorialização & $\begin{array}{l}\text { A reterritorialização é o movimento ou ação de } \\
\text { reconstrução de vínculos identitários e de enraizamento } \\
\text { de grupos populacionais e atividades em territórios, } \\
\text { em uma reorganização territorial influenciada pelo } \\
\text { cruzamento com novas lógicas sociais. Pode ocorrer no } \\
\text { mesmo lugar ou em outros lugares, ou simultaneamente } \\
\text { em vários lugares pela influência das tecnologias da } \\
\text { informação e comunicação e o enfraquecimento relativo } \\
\text { dos Estados-nações. }\end{array}$ & $\begin{array}{l}\text { Grupos de deslocados que buscam inserção em outros } \\
\text { países, com adaptações linguísticas, religiosas e choques } \\
\text { e enfrentamentos socioculturais. Inserção dos migrantes } \\
\text { em mercados de trabalhos e na economia de novos } \\
\text { países e regiões. Instalação de empresas estrangeiras } \\
\text { em países com normas e costumes diferentes do país de } \\
\text { origem (o mesmo pode ocorrer na lógica inter-regional } \\
\text { dentro de um país). }\end{array}$ \\
\hline Territorialidade & $\begin{array}{l}\text { Área de exclusiva ação de um Estado e seu aparato } \\
\text { jurídico, normativo e militar; remete à ação de poder } \\
\text { e de sentimento de pertencimento alimentado por } \\
\text { um indivíduo, grupo ou instituição em dado espaço; } \\
\text { deslocamentos e itinerários de grupos e indivíduos } \\
\text { que remetem a vínculos de identidade, podendo } \\
\text { variar em dias da semana, horários de um mesmo } \\
\text { dia (territorialidade cíclicas ou transitórias). Grupos } \\
\text { diferentes podem conceber territorialidades a partir de } \\
\text { um mesmo local. }\end{array}$ & $\begin{array}{l}\text { Pode-se referir ao território de planejamento e controle } \\
\text { de um Estado e de seus projetos e serviços. Também } \\
\text { pode ser usado como referência para identidades } \\
\text { territoriais que ainda não configuraram um território } \\
\text { político-jurídico-normativo, como os nacionalismos e } \\
\text { regionalismos. Atualmente é utilizado para referenciar } \\
\text { as práticas espaciais de grupos de indivíduos em } \\
\text { espaços urbanos, como é o caso das territorialidades } \\
\text { de movimento culturais e artísticos (movimento do Hip } \\
\text { Hop), das tribos urbanas, das igrejas, da prostituição, do } \\
\text { tráfico de drogas. }\end{array}$ \\
\hline
\end{tabular}




\begin{tabular}{|c|c|c|}
\hline $\begin{array}{l}\text { Multiterritorialidadee } \\
\text { transterritorialidade }\end{array}$ & $\begin{array}{l}\text { Associa-se à territorialidade instalada em vários lugares } \\
\text { simultaneamente, como é o caso das corporações } \\
\text { multinacionais e suas operações mundiais em rede } \\
\text { e deslocalizadas e, também, à incidência em um } \\
\text { mesmo lugar de várias lógicas e práticas territoriais, } \\
\text { como é o caso de centros urbanos e metropolitanos. } \\
\text { A transterritorialidade está associada aos espaços de } \\
\text { interação virtual via sistemas informacionais, com o } \\
\text { cruzamento de várias territorialidades e, ao mesmo } \\
\text { tempo, com a criação de novas territorialidades } \\
\text { desprovida de meio físico. }\end{array}$ & $\begin{array}{l}\text { Operações empresariais que se deslocalizam de um país } \\
\text { e região e se instalam em outro país e região, podendo } \\
\text { também manter essas operações simultaneamente } \\
\text { em vários países através de filiais, subcontratadas e } \\
\text { franquias. Concomitância espacial de territorialidades } \\
\text { sagradas (igrejas e áreas de influência) e profanas } \\
\text { (prostituição, tráfico, festas), de territorialidades urbanas } \\
\text { e rurais, diurnas e noturnas. Também podemos pensar } \\
\text { nas comunidades virtuais por gostos, preferências e na } \\
\text { expansão do comércio eletrônico. }\end{array}$ \\
\hline Microterritorialidade & $\begin{array}{l}\text { Territorialidades não institucionalizadas, não formais, } \\
\text { podendo estar vinculadas a grupos segregados ou } \\
\text { minorias; vincula-se mais a espaços de pertencimento } \\
\text { e representação do que espaços de controle, e são } \\
\text { evidenciadas em escalas menores (bairros, comunidades, } \\
\text { ruas, praças). }\end{array}$ & $\begin{array}{l}\text { Grupos unidos por diferentes ideais e preferências } \\
\text { culturais que convivem cotidianamente em um mesmo } \\
\text { espaço/lugar de encontro (alguns por opção, outros por } \\
\text { necessidade de discrição pela perseguição e segregação). } \\
\text { É o caso de skatistas e suas praças respectivas, os adeptos } \\
\text { do estilo punk e seus clubes, praças, os homoafetivos e } \\
\text { seus clubes e festas, os interessados em funk e seus bailes, } \\
\text { as escolas de samba de SP/RJ e suas comunidades e } \\
\text { bairros de pertencimento. }\end{array}$ \\
\hline Identidade territorial & $\begin{array}{l}\text { Vinculação com um território, em diferentes escalas } \\
\text { geográficas, por sentimento de pertencimento a uma } \\
\text { coletividade projetada no espaço, visto como meio de } \\
\text { reprodução, sobrevivência e preservação de hábitos, } \\
\text { valores e formas de trabalho/produção e sociabilidade. } \\
\text { É a identidade cultural projetada no território. }\end{array}$ & $\begin{array}{l}\text { Pode ser representada pelo pertencimento familiar; } \\
\text { sentimento de nacionalidade vinculado a um povo/ } \\
\text { Estado; prática de uma religiosidade atrelada a um } \\
\text { lugar; identificação histórica com o local de nascimento, } \\
\text { vivência e/ou trabalho; identidades étnico-culturais. }\end{array}$ \\
\hline
\end{tabular}

Org: $\mathrm{O}$ autor

\section{O TERRITÓRIO E O ENSINO DE GEOGRAFIA}

Esse trabalho de reflexão científica e de reflexão sobre o ensino de conceitos geográficos, como o de território, pode ser realizado com uso de canções populares. Kong (2009) reconhece que a música popular ainda não foi reconhecida como área de investigação geográfica, pontuando ser um elemento de penetração em todas as sociedades conhecidas, sendo constitutiva do cotidiano e da identidade das pessoas. Assim, delineia fatos que podem estimular a constituição de um programa de pesquisas sobre Geografia da música: $1^{\circ}$ ) A música de um determinado local traz imagens dele; $2^{\circ}$ ) A música pode servir como fonte primária para se compreender o caráter e identidade dos lugares; $3^{\circ}$ ) $\mathrm{A}$ música é um meio para as pessoas comunicarem suas experiências ambientais de "espaço" e de "lugar"; $4^{\circ}$ ) A música é o resultado de experiências ambientais.

Carney (2007) busca entender a música através dos lugares (topofilia) e entre diferentes lugares ou lugares não hegemônicos (heterotopia), estabelecendo padrões, similaridades, diferenças e conexões. Nesse sentido, o autor nos mostra as possibilidades de se estudar conjuntamente os lugares e a música através de uma hierarquia de lugares, revelando as diferentes formas de percepção e manifestação musical, conforme as ruas, bairros, cidades, estados e províncias, regiões e nações, elementos espaciais que são associados a diferentes tipos de lugares. Posto isso, os lugares também podem servir como: fontes de inovação e de resistência musical; fontes para composição musical através de seus elementos naturais; referências para movimentos espaciais de gêneros e subgêneros musicais e, por fim, como instrumento para percepção e construção de imagens e mapas mentais sobre os lugares. 
É possível compreender o lugar, em vinculação à discussão territorial, através do viés culturalista e fenomenológico dos espaços cotidianos de vivência e de percepção, ou pelo viés crítico (estruturalista, marxista ou até mesmo heterodoxo) dos espaços de resistência contra ordens hegemônicas. Considerando a primeira perspectiva, Buttimer (1982) associa o conceito de lugar ao de mundo vivido, aos espaços de identificação social e territorial. Lugar, por vezes confundido com territorialidade, expressa os fundamentos orgânicos, cognitivos, afetivos e simbólicos designativos associados às experiências do homem com o meio, experiências essas criadoras de significados e mediadas por símbolos. O espaço torna-se o horizonte da própria existência.

Já a segunda perspectiva, apresentada por Santos (1996), concebe os lugares pela dimensão espacial do cotidiano, como lócus privilegiados de uma ordem mundial, ou seja, a globalização capitalista se coloca como um conjunto de possibilidades cuja realização/concretização se dá nos lugares. São espaços em que se combinam a atividade racional e simbólica dos homens pelo efeito de proximidade e solidariedade, criando-se uma consciência associada à densidade social que pode gerar assimilação ou resistência em relação aos vetores macro ou globais, situando-se na dialética do local-global.

No lugar - um cotidiano compartido entre as diversas pessoas, firmas e instituições - cooperação e conflito são a base da vida em comum. Porque cada qual exerce uma ação própria e a vida social se individualiza; e porque a contiguidade é criadora de comunhão, a política se territorializa, com confronto entre organização e espontaneidade. O lugar é o quadro de uma referência pragmática do mundo, do qual lhe vêm solicitações e ordens precisas de ações condicionadas, mas é também o teatro insubstituível das paixões humanas, responsável, através da ação comunicativa, pelas mais diversas manifestações de espontaneidade e criatividade. (SANTOS, 1996, p. 258).

Desse modo, percebe-se a vinculação entre os conceitos geográficos e as referências e contextualizações que as músicas nos oferecem para seu entendimento, servindo como recurso científico e didático para seu entendimento e apropriação, um recurso a favorecer a transposição didática. Para Mello (s/d), a transposição didática define a transformação de objetos de conhecimento (saber científico e práticas sociais) em objetos de ensino, através da: a) seleção e recorte do conteúdo; b) ênfase em alguns aspectos ou temas; c) divisão do conhecimento para sua compreensão; d) distribuição do conhecimento no tempo, um ordenamento; e) organização e apresentação dos conteúdos (textos, gráficos e mapas). Boligian (2003) complementa, baseado em Chevellard (1991), que a transposição didática envolve um esforço de transformar um objeto de saber científico, como é o caso do conceito científico, em um objeto de ensino, um saber a ser ensinado em sala de aula.

Em texto anterior (FUINI, 2013), destacamos que as letras musicais podem ser utilizadas no ensino de conceitos geográficos, em perspectiva sócio-histórico-cultural e construtivista (CAVALCANTI, 1998), considerando a importância de formação de um raciocínio espacial no processo de construção de conhecimentos pelo aluno mediado pelo professor. Assim, utilizamos a metodologia abaixo baseada em oito níveis de ensinoaprendizagem no sentido de usar a música como instrumento para auxiliar na construção do conceito de território. 
Quadro 2 - Metodologia para ensino de conceitos geográficos através da música considerando o processo de construção do conhecimento e do raciocínio espacial

- Propicia atividade mental e física dos alunos, estimulando a interação do aluno com o saber escolar através de seus instrumentais cognitivos (observar, localizar, compreender, descrever, representar). Trata-se de tarefa inicial de audição e análise da música e apropriação de significados que as letras permitem depreender, sugerindo debate sobre essas visões;

- Considera a vivência dos alunos como dimensão do conhecimento, captando o significado que os alunos dão aos conceitos científicos. Nesse estágio, o procedimento de buscar identificar e explicar os processos sócio-espaciais descritos nas músicas faz o aluno expor seus conhecimentos prévios e tecer relações com o mundo vivido e conhecido;

- Estabelece situações de interação e cooperação entre os alunos, contribuindo para o processo de socialização e desenvolvimento de habilidades por meio do diálogo entre conhecimentos e visões diferentes sobre o mesmo assunto. Neste estágio, é oportuno oferecer alguns questionamentos sobre a letra da música e a percepção de conceito que ela traz, estimulando a interação entre os alunos que podem trabalhar organizados em grupos;

- Conta com a intervenção do professor no processo de aprendizagem dos alunos, colocando problemas e informações para a reconstrução de conteúdos. Com base no encaminhamento do diálogo, o professor pode desafiar os alunos propondo atividades reflexivas a partir de trechos da letra musical, propiciando a construção de sentidos ao texto e seu contexto socioeconômico e espacial;

Apresenta informações, conceitos e análise de dados, decodificando significações e avaliando criticamente as informações. O professor acrescenta à análise da música determinadas informações sobre lugares, regiões e território, sendo elas em gráficos, mapas, fotografias, etc., solicitando aos alunos que extraiam algumas conclusões sobre os mesmos e produzam seu próprio conhecimento;

- Propicia situações de diálogo entre alunos e destes com o professor, ressaltando-se a importância da interação social para a apropriação em conhecimento sobre as matérias de ensino. Nessa etapa, o professor estimula a construção de conclusões parciais pelos grupos de alunos e busca sistematizá-las em um quadro geral, compartilhando conhecimentos e informações entre grupos;

- Promove a auto e sociorreflexão dos alunos, estimulando o aluno a aprender e direcionar os próprios processos mentais, com a ajuda de palavras ou signos, passos essenciais do processo de formação de conceitos. Nesse momento pode ser feita uma discussão coletiva em sala de aula, oportunidade para a síntese do resultado das atividades e direcionamento do processo de construção de conhecimentos; - Oferece alternativas ao acompanhamento e controle dos resultados, considerando a natureza do objeto de conhecimento e o tipo de aprendizagem requerida, compreendendo a dinâmica de cada um, suas dificuldades e potencializando as possibilidades de ensino. Ao final do processo de aprendizagem, o professor, como agente ativo, pode fazer o uso de uma avaliação de tipo contínua, observando a participação de cada um dos alunos nas atividades propostas durante todo o período analisado; e uma avaliação de tipo formativa e sistemática, sugerindo a construção de um texto individual ou coletivo que seja alvo de uma conceituação.

Org: Fuini (2013), baseado em Cavalcanti (1998)

Oliveira e colaboradores (2005, apud FUINI, 2013) afirmam que a música, como um meio de comunicação, pode ser considerada um apoio pedagógico e instrumento facilitador na superação de algumas barreiras do processo de ensino-aprendizagem, 
criando situações em que o aluno se sinta atraído pelas propostas do professor e o mesmo se sinta seguro para propor situações de aprendizagem sobre determinados conteúdos.

A música Saudosa Maloca foi lançada pelo famoso sambista paulista Adoniran Barbosa em 1951, aparecendo como exemplo emblemático do processo de urbanização e metropolização do espaço e avanço da especulação imobiliária (na capital paulista), com a segregação das classes mais pobres no espaço urbano que perdem suas moradias junto às áreas centrais (os chamados cortiços ${ }^{1}$ ) e migram para a periferia.

Figura 1 - Fotografia de cortiço localizado no bairro do Bexiga em São Paulo, do período de 1919 a 1925

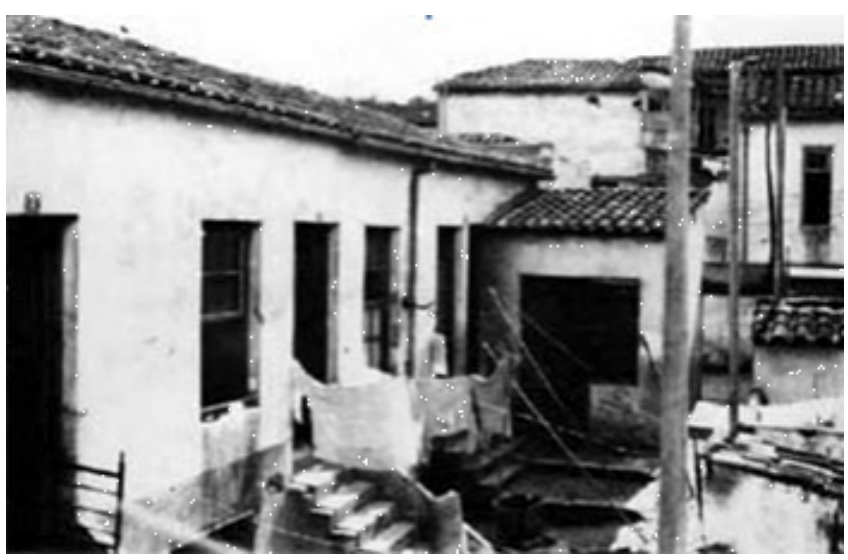

Fonte: Geraldo Horácio de Paula Souza/Acervo da FAU/ USP/http://www.historiaemhistoria.com.br
Figura 2 - Demolição de prédios antigos para alargamento da rua Líbero Badaró em São Paulo, em 1912

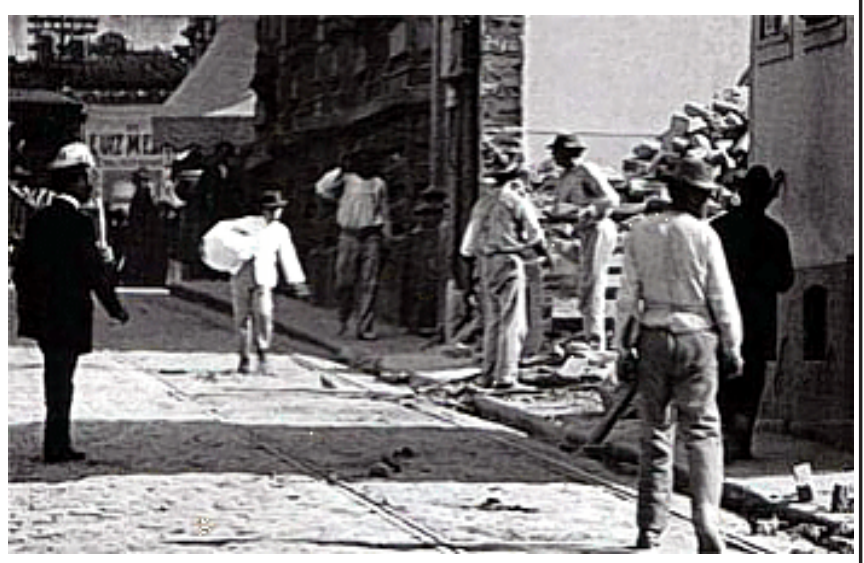

Fonte: Aurélio Becherini/Biblioteca de Ciências Humanas da UEL/

Corrêa (2001) define a periferia como áreas mais afastadas dos núcleos centrais e formadas pela justaposição de loteamentos ("um mosaico irregular"), com precariedade de equipamentos de consumo coletivo, além da prática de compra a prazo da habitação, geralmente autoconstruções precárias e não terminadas. São também as áreas mais suscetíveis a doenças e moléstias, enchentes e deslizamentos de terras e a assunção da criminalidade. No entanto,

[...] é na periferia que se formam os movimentos de moradores que reivindicam melhores condições de vida, uma cidadania plena [...]. A periferia não se refere apenas à localização distante. Ganha também um sentido de metáfora ao ser identificada como sinônimo de exclusão, de precariedade das condições de vida. (CORRÊA, 2001, p. 162).

1 Os cortiços podem ser definidos como prédios de dois ou três pavimentos que serviam como moradia coletiva para a classe trabalhadora e suas famílias, muito comum em São Paulo e no Rio de Janeiro de fins do século XIX aos anos 1950 e 1960. Com as necessidades de fluidez territorial advindas da intensificação do uso do automóvel, avenidas e ruas foram alargadas na metrópole paulistana e cortiços foram demolidos para abrir espaço a esses sistemas de engenharia. Além disso, a valorização dos terrenos próximos às áreas centrais dotadas de infraestrutura e as campanhas para requalificação e higienização urbana que associavam os cortiços à decadência, doenças e criminalidade, fizeram com que esses "sobrados antigos" fossem retirados gradualmente da paisagem urbana, sobretudo das áreas mais valorizadas, pois comprometiam sua estética. Assim, a população pobre vai sendo crescentemente direcionada para a periferia ou áreas de risco, com a construção de conjuntos populares e também pela ocupação desordenada e irregular de terrenos urbanos, formando-se as favelas. Segundo Corrêa (2001), as favelas são o resultado da ação de grupos socialmente excluídos que ocupam terrenos, públicos ou privados, via de regra inadequados para valorização fundiária e promoção imobiliária, grupos estes que agem espontaneamente como estratégia de sobrevivência e de resistência em um sistema social excludente. A favela é uma forma alternativa de produção do espaço com elevada densidade populacional, com casebres toscos ou melhorados, de alvenaria, em área cuja ação limitada do Estado conduz a uma infraestrutura precária, com ausência ou escassez de serviços básicos. 
Escrita em linguagem coloquial, típica dos trabalhadores pobres e grupos populacionais com pouca instrução formal, a música traz uma série de trechos que remetem às identidades territoriais ("Foi ali seu moço [...]/Construímo nossa maloca", "Passemos dias feliz de nossa vidas"), à territorialização do capital imobiliário ("Esse edifício arto" / "Veio os home c'as ferramenta, o dono mandô derrubá") e à desterritorialização das classes pobres ("Peguemo todas nossas coisas"| "Fumo pro meio da rua"| "Nóis arranja outro lugar"), gerando aglomerados de exclusão metropolitanos ("Hoje nóis pega paia nas grama dos jardins").

Segundo Haesbaert (1999), os aglomerados de exclusão são resultantes do processo de desterritorialização extrema. Os aglomerados de exclusão, identificados, geralmente, com refugiados e deslocados de situações de guerra, fome e pobreza extrema, com afetados por secas e intempéries climáticas, e por população associada à ocupação desordenada em favelas e áreas ocupadas pelo tráfico de drogas, seriam definidos por uma certa fluidez marcada pela instabilidade e insegurança constantes, principalmente em termos de condições materiais de sobrevivência, pela violência frequente e pela mobilidade destruidora de identidades.

Trata-se [...] de espaços sobre os quais os grupos sociais dispõem de menor controle e segurança, material e simbólica. A desterritorialização arrasadora dos aglomerados excludentes produz assim o anonimato, a anulação de identidades e a ausência praticamente total de seus habitantes. (HAESBAERT, 1999, p. 193).

O contexto histórico era o do Brasil em processo de industrialização e com discurso nacionalista de crescimento e modernização econômica, com fortes movimentos de êxodo rural. As territorialidades do trabalho e da moradia ("pega paia", "casa veia", "maloca") também são evidenciadas na música. Os territórios econômicos (do mercado imobiliário, da valorização dos terrenos nas cidades), políticos (Estado favorecendo os grandes empreendimentos imobiliários - que privatizam o espaço urbano - e omitindo-se da responsabilidade pelas populações excluídas e sem moradia) e culturais (solidariedade entre pessoas no lugar, mesmo sem condições financeiras, associação de felicidade com o lugar).

Nesse sentido, o lugar ganha uma dupla conotação na análise do texto musical: como espaço de vivência cotidiana, representado pelas lembranças e saudades do local de moradia (a "maloca"), e também como espaço de resistência e de lutas sociais, identificado na passagem da destruição e do ato de "Mato Grosso quis gritar", indicando contrariedade apesar de um aparente conformismo ("Os home tá com a razão").

É o período de implantação de um meio técnico-científico no Brasil, com a definição de uma região concentrada formada pelo Sudeste, Sul e Centro-Oeste e início de uma urbanização interior do país, com a integração econômica do espaço nacional, além da criação de um embrião de transportes modernos em São Paulo e consolidação da hegemonia paulista nos investimentos industriais e em serviços.

Como apontam Santos e Silveira: "A modernização do país, já iniciada sob o regime de Getúlio Vargas, facilitara a concentração econômica e espacial. A rápida expansão da indústria no 'centro' passava a exigir mais mercados, não apenas fora, mas também dentro do país." (SANTOS; SILVEIRA, 2010, p. 44). 
Serve-se do mesmo contexto assinalado acima a música Sobradinho, de composição da dupla Luís Carlos Sá e Guttemberg Guarabyra, em fins dos anos 1970. A canção se refere ao contexto de construção da usina hidrelétrica de Sobradinho, no rio Sao Francisco, em 1976, e o impacto social e ambiental que o lago criado exerceu sobre as vilas e cidades que foram inundadas, remetendo à profecia de Antônio Conselheiro, líder da revolta de Canudos: "O sertão vai virar mar".

Figuras 3 e 4 - Imagem da Usina Hidrelétrica de Sobradinho em construção e já terminada
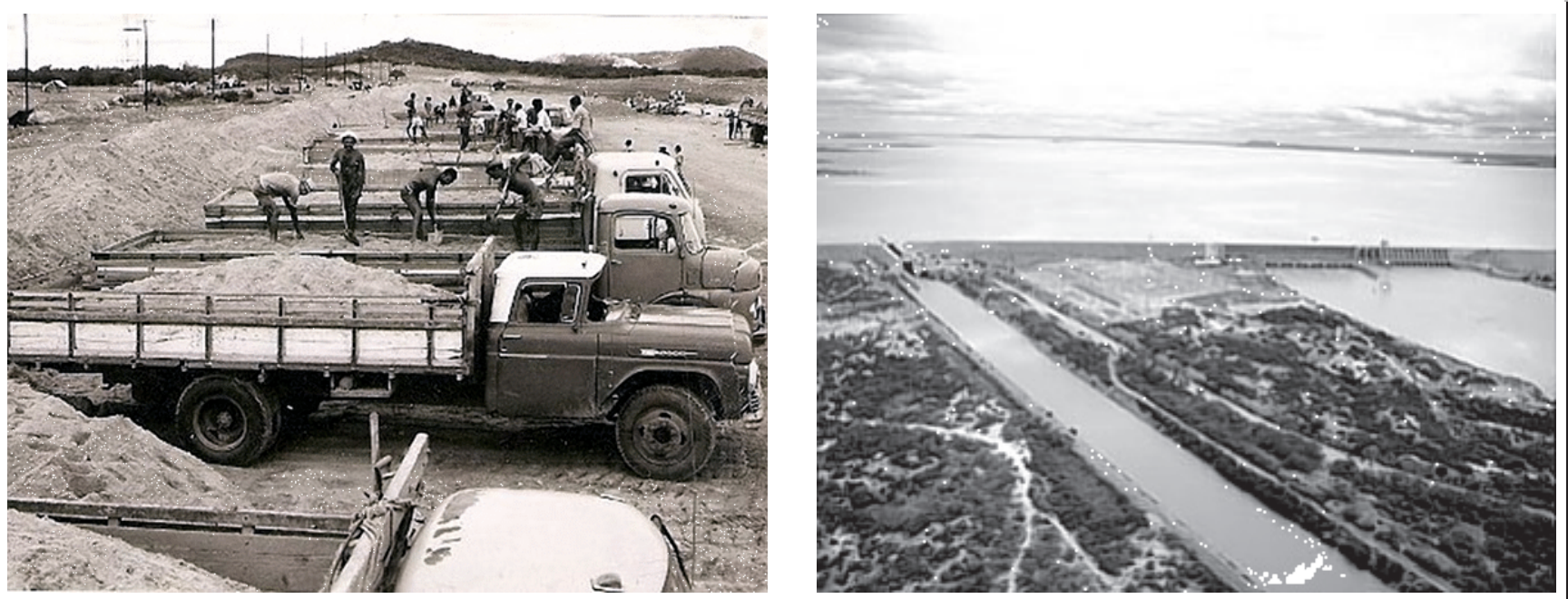

Fontes: http:/ / www.geraldojose.com.br/ http:/ / aristides.ciencias.zip.net/

Figura 5 - Construção da antiga cidade de Remanso, umas das inundadas pelo Lago de Sobradinho

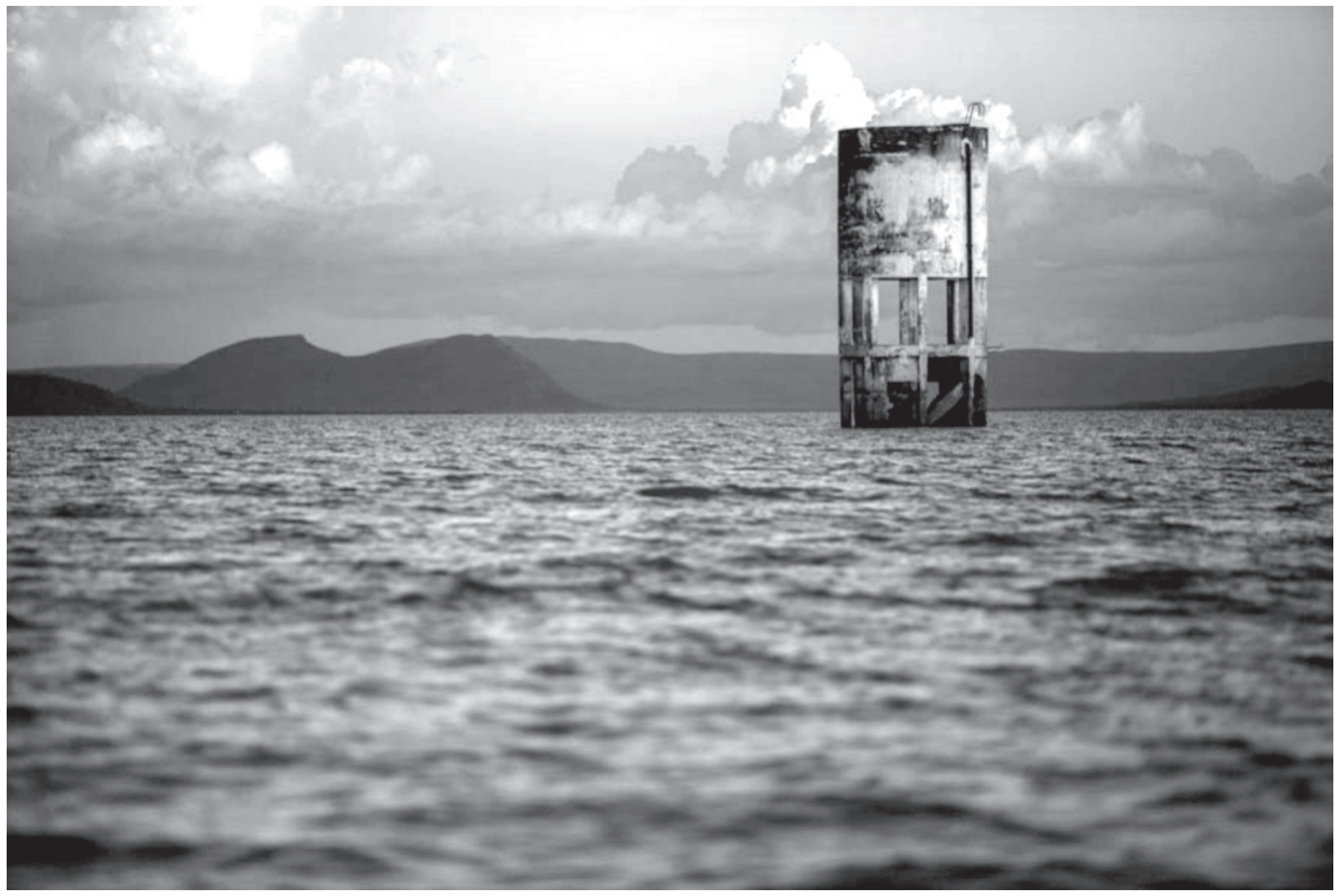

Fonte: http://www.nitroimagens.com.br 
A perspectiva da territorialização da hidrelétrica, com a imposição do discurso econômico, levou à desterritorialização de cerca de 70 mil pessoas das localidades citadas na música ("Casa Nova", "Sento Sé", "Pilão Arcado"). A perspectiva de apropriação e produção do espaço ("O homem chega e já desfaz a natureza", "tira gente, põe represa"), originária do território, remete também ao território político da Bahia e à dissolução de diversas territorialidades e identidades culturais que se associavam aos territórios como espaços vividos ("Por baixo d'água lá se vai a vida inteira"), produzindo a desterritorialização com exclusão ("O povo vai se embora com medo de se afogar"). O contexto histórico era do Brasil sob égide do regime militar autoritário e com planos de integração nacional via infraestrutura energética e de circulação, com a meta do crescimento econômico como projeto de país sendo utilizada inclusive para reprimir, de forma violenta, grupos contrários ao regime.

A territorialização, em termos políticos e econômicos, expressa a ideia de espaço controlado e apropriado por relações de poder institucionalizadas, geralmente associadas ao poder político do Estado, além de também servir como fonte de recursos econômicos ou associada à relação capital-trabalho e à luta de classes, delineadas pela divisão territorial do trabalho (HAESBAERT, 2006). Na canção Sobradinho, o território político da ação do Estado ditatorial em um projeto de infraestrutura é interdependente do território econômico da produção de energia para as atividades econômicas agrícolas e industriais, em contraponto à desterritorialização das famílias dedicadas à agricultura familiar e a ruptura dos vínculos sociais e culturais que ali existiam. Essa desterritorialização, com quebra de vínculos de identidade e, em alguns casos, dos meios de sobrevivência, leva à necessidade de busca de uma reterritorialização precária, em áreas mais afastadas, com a imposição do discurso do "moderno" versus o "arcaico", o "atrasado".

A música Aluga-se, de Raul Seixas e Cláudio Roberto Azevedo, lançada em 1980, ainda no período militar, traz uma crítica ao modelo econômico brasileiro. Sua letra contém fortes elementos da perspectiva de território econômico e político ("Negócio bom assim ninguém nunca viu"/"Alugar o Brasil"), colocando em discussão a soberania nacional e a identidade territorial brasileira face à internacionalização do capitalismo com as multinacionais ("Os estrangeiro eu sei que eles vão gostar"), com a desterritorialização de pessoas de lugares e regiões ("A Amazônia éo jardim do quintal"), pela mobilidade do capital transfronteiriço ("O dólar deles paga o nosso mingau"), com homogeneização cultural ("É tudo free, vamo embora") e deslocalização exacerbada face à "tirania do dinheiro", como observa Santos (2000). A letra traz ainda elementos sobre a territorialidade de um "povo", com as ideias de identidade e símbolos nacionais de referência socioespacial (Brasil, Amazônia, Atlântico) em contraposição ao estrangeiro (dólar, a palavra em inglês free). 
Figura 6 - Imagem recente da área de mineração de bauxita da companhia estadunidense Alcoa no município de Juruti, oeste do Pará. A companhia está instalada no país desde 1965

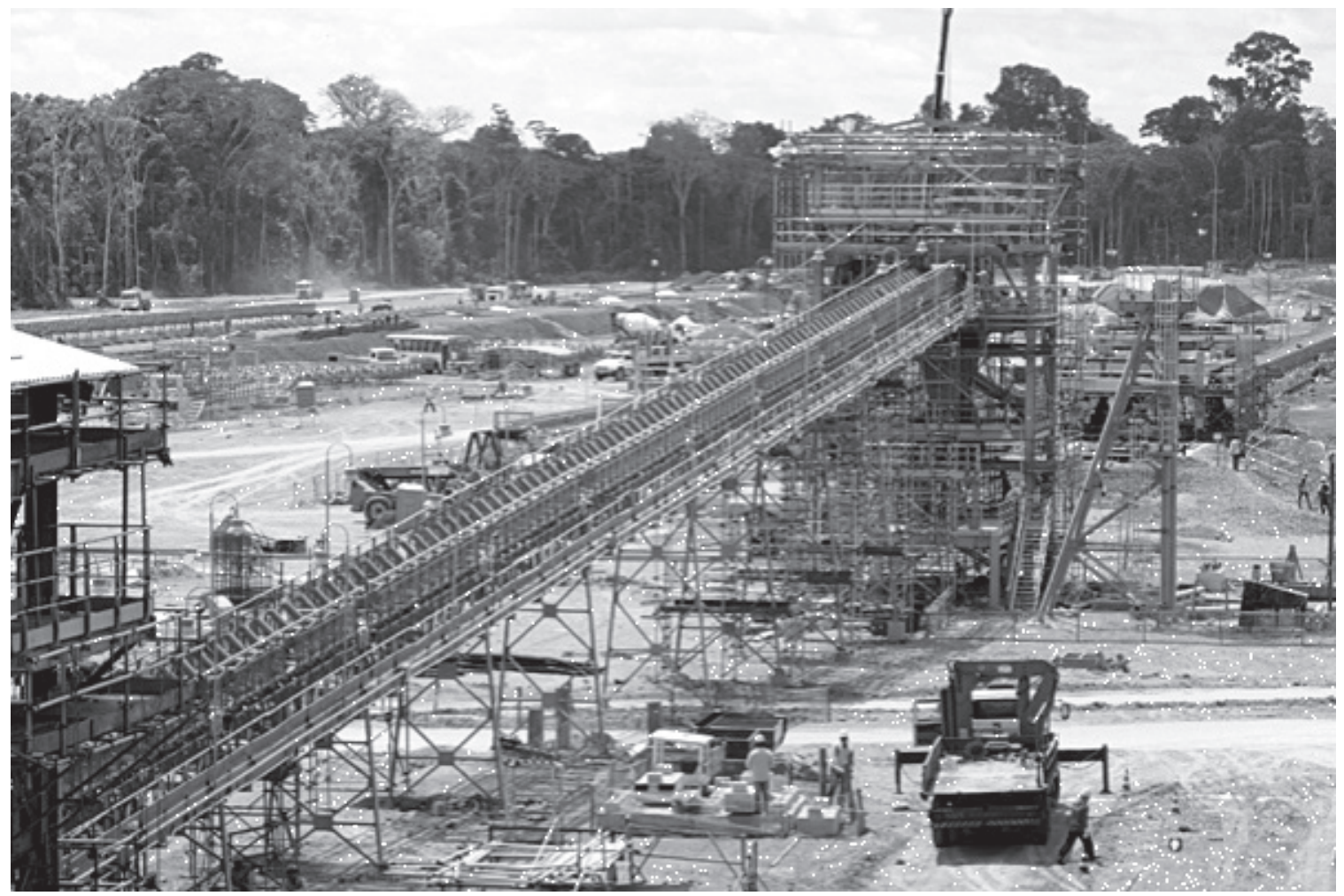

Fonte: http://www.alcoa.com

Figura 7 - Construção da primeira unidade de produção de automóveis no Brasil (inaugurada em 1957), a companhia alemã Wolkswagen

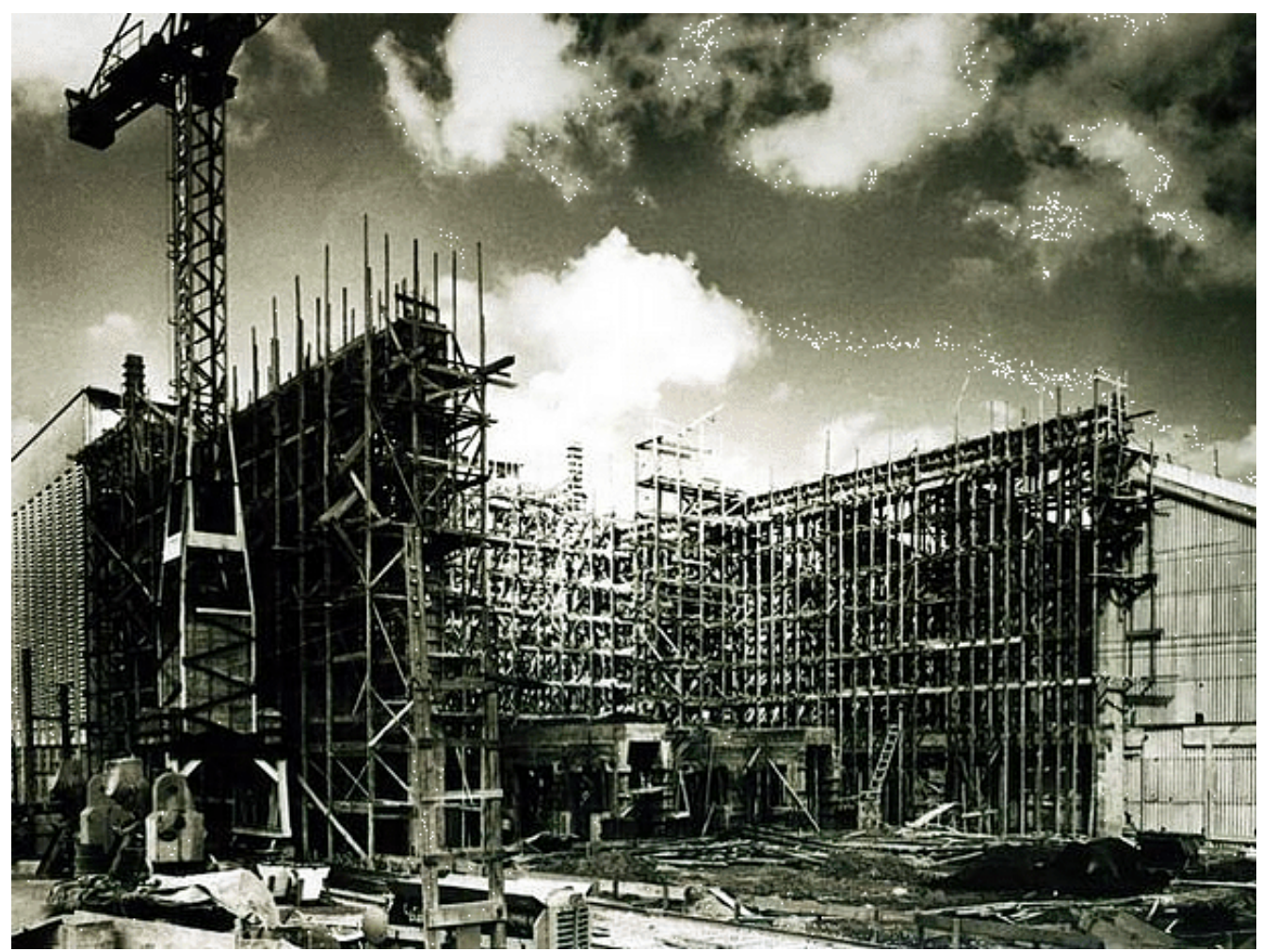

Fonte: http:/ / www.economia.terra.br 
A música Disneylândia, composta por Arnaldo Antunes e Paulo Miklos, da banda paulistana Titãs, lançada em 1992, faz menção ao processo de globalização e à mobilidade crescente do capital, das pessoas, produtos, dos idiomas e elementos culturais, nesse mundo "aparentemente" integrado e sem fronteiras.

A ideia de desterritorialização traz uma associação direta com a perspectiva da globalização. Santos (1996) afirma que a ordem global (que funda as escalas superiores ou externas à escala do cotidiano) é desterritorializada, separando o centro da ação da sede da ação em um "espaço movediço" de pontos dependentes de fatores externos. A ordem local, em contraponto, seria reterritorializadora, pois reúne em uma mesma "lógica interna todos os seus elementos: homens, empresas, instituições, formas sociais e jurídicas e formas geográficas, em um cotidiano localmente vivido" (SANTOS, 1996, p. 272-273).

A canção, desse modo, serve como relato fictício de um mundo interconectado com diversas cenas e situações de interdependência, nos remetendo constantemente à perspectiva da desterritorialização e da reterritorialização ("Filho de imigrantes russos, casado na Argentina com uma pintora judia"), com a saída de pessoas de alguns países e lugares e fixação e enraizamento em outros. Remete-nos também a territórios (em movimento de desterritorialização) em perspectiva econômica ("Multinacionais japonesas instalam empresas em Hong Kong", "matéria-prima brasileira"; "madeira colombiana"), político-jurídica ("armênios naturalizados no Chile", "crianças iraquianas fugidas da guerra", "não obtém visto no consulado americano do Egito") e cultural ("Literatura grega adaptada para crianças chinesas da comunidade europeia"). Além disso, expõe também vários elementos de territorialidades e microterritorialidades ("camelôs no bairro mexicano de Los Angeles").

Haesbaert (1999) afirma que nesse mundo dito globalizado, as identidades aparecem cada vez mais descontínuas, fragmentadas e sobrepostas, criando-se novas formas de identificação social, em contraposição às identidades territoriais e monolinguísticas do período moderno. Assim, para o autor, emergem três tipos de identidades territoriais atuais: a) as globais, que implicam a própria dissolução das identidades; b) as de resistência, tipicamente saudosistas e que reforçam memórias coletivas antigas, como nacionalistas ou etnicismos; c) as novas identidades pluriculturalistas, fruto da interação global-universal e local-particular. A letra de Disneylândia apresenta um mundo de aparente identidade transterritorial (ou desterritorializada), em sintonia com seu título, que remete a uma espécie de não-lugar ou pseudo-lugar (lugares de passagem, de massificação cultural, sem permissão para criar elementos de identidade duradouros), mas, ao final, com o exemplo dos "egípcios" banidos nos Estados Unidos, retoma-se o vínculo identitário com os territórios de origem, servindo tanto para a auto-afirmação e orgulho quanto para a segregação, desprezo e vergonha. 
Figura 8 - Bairro da Liberdade em São Paulo, tradicional área da capital paulista que concentra imigrantes japoneses, chineses e coreanos

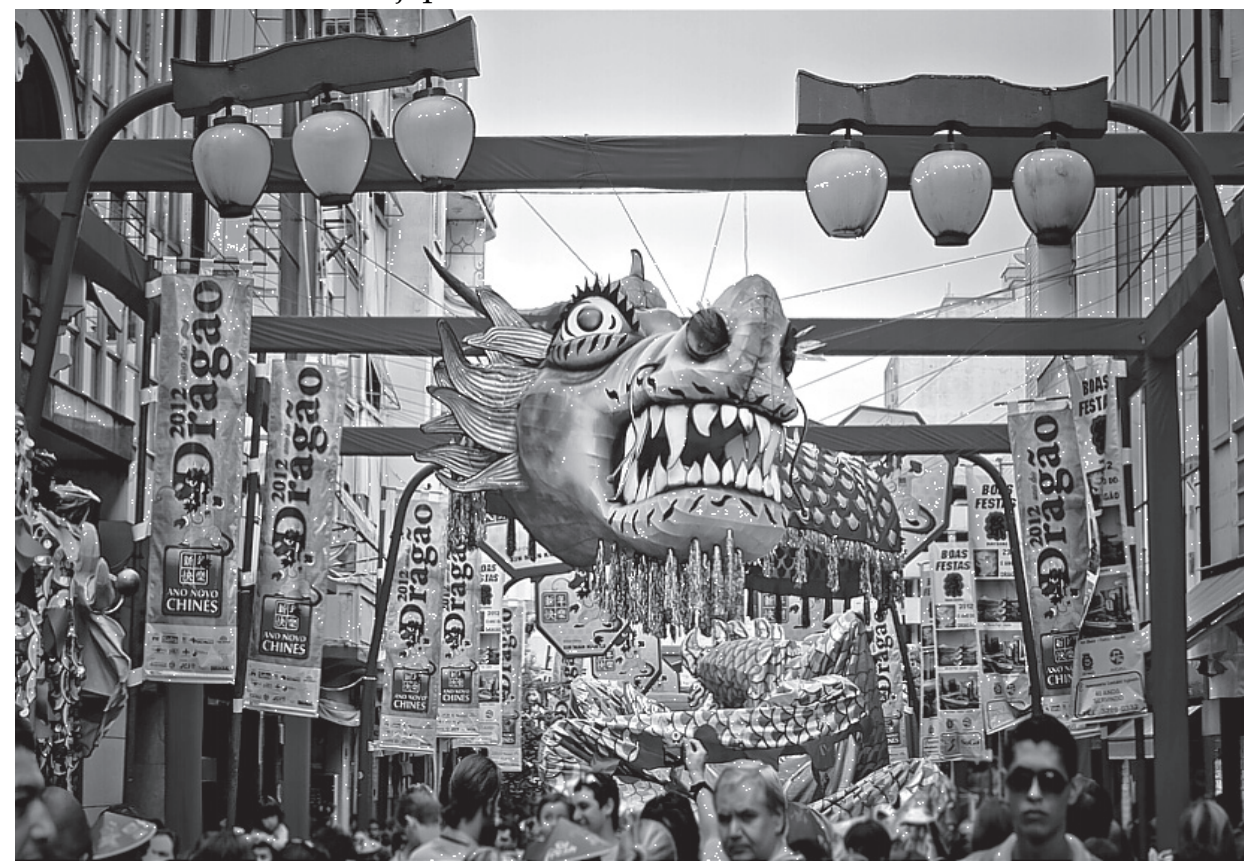

Fonte: http:/ / restaurantenagoya.com.br/blog/bairro-da-liberdade/

Figura 9 - Imigrantes subsaarianos esperam por trabalho debaixo da ponte de Gargaresh, no oeste de Trípoli, a meio caminho da Ilha de Lampedusa, no Mar Mediterrâneo, no Sul da Itália

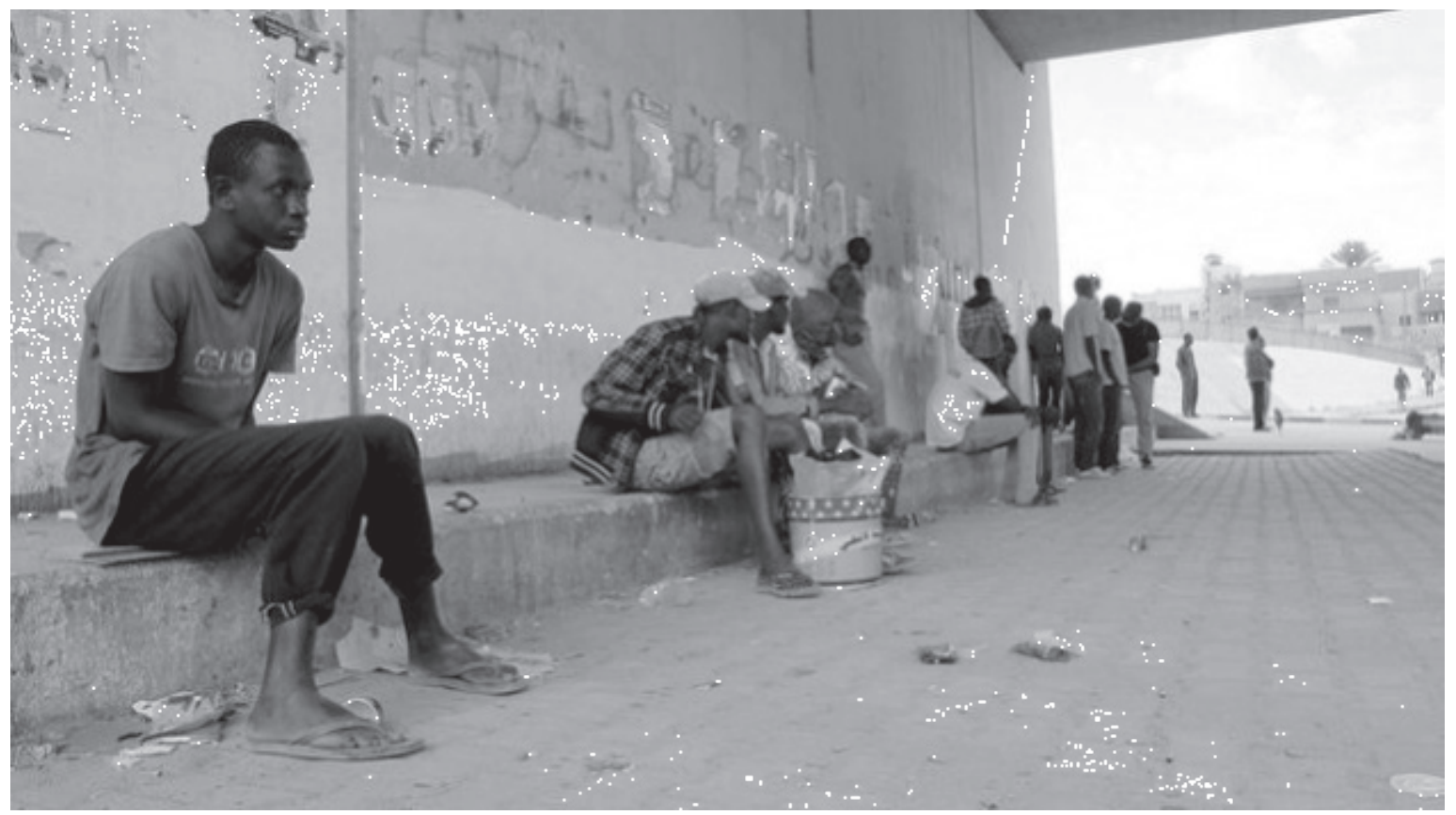

Fonte: http://www.envolverde.com.br

A canção Disneylândia, portanto, remete mais à característica da desterritorialização como fenômeno econômico, político e cultural criado a partir e pela globalização contemporânea. A globalização econômica contemporânea se define pela integração desigual dos países do globo nas redes criadas pelas tecnologias de informação e comunicação 
(internet, satélites, fibra óptica), pelo sistema financeiro mundial, pelo comércio mundial alicerçado na divisão internacional do trabalho, impetrada pelas corporações multinacionais e pela hegemonia do discurso neoliberal de Estado mínimo, em uma geometria de poder variável que define os "espaços de comando", os globalizadores, e os "espaços comandados", os globalizados. Seu conduto, portanto, seria o modelo de acumulação flexível, pautado nos esquemas de subcontratação e terceirização interempresariais, na desregulamentação público-estatal, na reestruturação da produção e sua automatização crescente e na flexibilização/precarização do trabalho.

Haesbaert (2006, p. 173) afirma, assim, que:

[...] a desterritorialização é vista praticamente como sinônimo de globalização econômica ou, pelo menos, como um de seus vetores ou características fundamentais, na medida em que ocorre a formação de um mercado mundial com fluxos comerciais, financeiros e de informações cada vez mais interdependentes de bases territoriais bem definidas, com a dos Estados-nações.

No entanto, o mesmo autor pontua que "a fragmentação e fragilização que atingiram o campo do trabalho e da produção nas últimas décadas podem ser consideradas componentes essenciais para configurar os processos de desterritorialização" (HAESBAERT, 2006, p. 173).

\section{CONSIDERAÇÕES FINAIS}

Para Santos (2002), o retorno do território, como noção importante para a análise social, se dá como superação do conceito herdado da modernidade que limitava o território como fundamento do Estado-nação, que o moldava. O território, junto do povo e da soberania, é um dos elementos constituintes do Estado e se transforma em espaço quando ocorre seu uso pelo povo. "O território é imutável em seus limites, uma linha traçada de comum acordo ou pela força. Este território não tem forçosamente a mesma extensão através da história." (SANTOS, 2002, p. 233).

Assim, com a transnacionalização do território, criam-se novas sinergias e novos vetores de funcionamento do território, como as perspectivas dialéticas que colocam lado a lado as horizontalidades e verticalidades, os lugares contíguos e os lugares em rede, o acontecer homólogo e o acontecer hierárquico, as normas locais e as normas globais.

Segundo Haesbaert (2006), a identidade transnacional ou a multiterritorialidade se refere à ideia de um território em movimento, um território dinâmico, que pode estar associado à grupos ou à multidão. Além disso, essa multiterritorialidade é criada através de identificações variadas, tanto no sentido de uma consciência multi ou pluriescalar, com múltiplos espaços de referência identitários fomentados pelo domínio dos fluxos e mobilidade em um mundo de relações instantâneas; quanto pela égide da flexibilidade nas relações de trabalho e de produção, levando à deslocalização econômica e a hibridização cultural que dificulta a formação clara de identidade culturais. Assim, sem dúvida, são 
colocados os desafios para nossa forma de ver, pensar e representar os territórios na contemporaneidade.

Nesta análise foi possível delinear alguns caminhos fundamentais da discussão sobre o território, em sua dimensão inerente ao próprio conhecimento geográfico e em suas possíveis interfaces com a música e sua perspectiva educativa. Foi possível compreender que na análise territorial caminham em conjunto as dimensões material e imaterial (SAQUET, 2007), além de se associar também a diversos contextos históricos e espaciais de análise no plano das dimensões políticas, econômicas, sociais e culturais. Pensando em sua dinâmica, é possível aproximar o território do universo das relações socioespaciais mais amplas ou mais recônditas através do olhar das múltiplas territorialidades humanas, enfatizando também a natureza e a dinâmica dos fluxos materiais e imateriais que alimentam as desterritorializações, reterritorializações, e até mesmo as microterritorializações, envolvendo relações formais ou informais, entre instituições estatais, atividades econômicas ou entre diversos grupos sociais, mais ou menos coesos.

Neste corpo teórico e de método, investigou-se como o rico acervo musical pode fornecer indícios para se fazer uma investigação geográfica, mais particularmente do território. A partir de uma seleção de repertório do amplo universo musical brasileiro, torna-se mais claro o componente de relações de poder, apropriação, uso e controle que definem o território por meio de passagens de canções que ilustram determinados momentos da história e de fatos ocorridos em determinados lugares. Assim, expõe-se o esforço analítico de aproximar espaço e cultura através do uso de textos musicais como recursos da pesquisa geográfica e, adicionalmente, aproximando também esse recurso do ambiente educativo.

Na educação geográfica, a transposição didática do conceito de território pode se fazer valer, na atualidade, da riqueza de interpretações que a pesquisa geográfica dispõe, em uma verdadeira dissecação e compartimentação epistemo-ontológica visando a uma posterior síntese de significado mais profundo, utilizando a canção como elemento de facilitação ou de incremento da aprendizagem, auxiliando na indução do raciocínio geográfico e na formação de uma consciência espacial que qualifique o território, em suas diversas naturezas e escalas, e desenvolva sua apropriação como referencial do conhecimento.

Desse modo, concebemos a importância de se oportunizar a formação de um raciocínio geográfico e espacial sobre o conceito de território e alguns de seus entendimentos e designações atuais, salientando o valor dos conceitos como eixos fundamentais do trabalho de pesquisa e ensino em Geografia, bem como reconhecendo o papel das canções populares como elementos de contextualização, representação e identificação relacionados aos diversos territórios, territorializações e territorialidades (FUINI, 2012). 


\section{REFERÊNCIAS}

ANDRADE, Manuel C. A questão do território no Brasil. 2. ed. São Paulo: Hucitec, 2004.

BOLIGIAN, Levon; ALMEIDA, Rosângela D. A transposição didática do conceito de território no ensino de Geografia. In: GERARDI, Lúcia H. Ambientes: Estudos de Geografia. Rio Claro: Programa de Pósgraduação em Geografia - UNESP; Associação de Geografia teorética - AGETEO, 2003. p. 235-248.

BONNEMAISON, Joel. Viagem em torno do território. In: CORREAA, Roberto L.; ROSENDAHL, Zeny, Geografia cultural: Um século (3). Rio de Janeiro: Eduerj, 2002.

BUTTIMER, Anne. Aprendendo o dinamismo do mundo vivido. In: CHRISTOFOLETTI, Antonio, Perspectivas da Geografia. São Paulo: Difel, 1982.

CARNEY, George. O. Música e Lugar. In: CORRÊA, Roberto Lobato; ROSENDAHL, Zeny, Literatura, Música e Espaço. Rio de Janeiro: EdUERJ, 2007.

CASTELS, Manuel. A sociedade em rede. 6. ed. São Paulo: Paz e Terra, 2003.

CAVALCANTI, Lana. S. Geografia, escola e construção de conhecimentos. Campinas, SP: Papirus, 1998.

CHESNAIS, François. A mundialização do capital. São Paulo: Xamã, 1996.

CLAVAL, Paul. O território na transição da pós-modernidade. Geographia, Niterói, UFF, Programa de Pós-graduação em Geografia, ano 1, n. 2, 1999.

CHELLOTI, Marcelo C. Reterritorialização e identidade territorial. Sociedade e Natureza, Uberlândia, UFU, v.1, n. 22, p. 165-180, abr. 2010.

CORREAA, Roberto. L. Trajetórias Geográficas. Rio de Janeiro: Bertrand Brasil, 2001.

COSTA, Benhur P da. As relações entre os conceitos de identidade, território e cultura no espaço urbano: Por uma abordagem microgeográfica. In: ROSENDAHL, Zeny; CORRÊA, Roberto Lobato, Geografia: Temas sobre cultura e espaço. Rio de Janeiro: Eduerj, 2005.

FORTUNA, Carlos. (Micro)territorialidades: Metáfora dissidente do social. Terra Plural, Ponta Grossa, PR, UEPG, v. 6, n. 2, p. 199-214, jul./dez. 2012.

FUINI, Lucas. L. O ensino de conceitos geográficos e de seus conceitos através da música. Geografia, Rio Claro, SP, Ageteo, v. 38, n.1, p. 93-106, jan./abri. 2013.

FUINI, Lucas. L. Territórios e territorialidades da música: Explorando a letra musical como relato de cotidianos e lugares. Anais do II Seminário Internacional sobre Microterritorialidades nas Cidades, Unesp, Presidente Prudente, 2012.

HAESBAERT, Rogério. O mito da desterritorialização: Do "fim dos territórios" à multiterritorialidade. 2. ed., Rio de Janeiro: Bertrand Brasil, 2006.

HAESBAERT, Rogério. A desterritorialização: Entre as redes e os aglomerados de exclusão. In: CASTRO, I. E., et al., Geografia: Conceitos e temas. Rio de Janeiro: Bertrand Brasil, 1999, p. 165-206.

HAESBAERT, Rogério. Identidades territoriais. In: ROSENDAHL, Zeny; CORREAA, Roberto L., Manifestações da cultura no espaço. Rio de Janeiro: Eduerj, 1999.

HAESBAERT, Rogério; RAMOS, Marina T. O mito da desterritorialização econômica. Geographia, ano 6, n. 12, p. 25-48, 2004.

MELLO, Guiomar. N. Transposição didática, interdisciplinaridade e contextualização. s/d. Consultado em <http.:/ / namodemello.com.br>. Acesso em: 19 nov. 2013.

MORAES, Antônio C. R. Ideologias geográficas. São Paulo: Hucitec, 1988.

MORAES, Antônio C. R. Território e história no Brasil. São Paulo: Hucitec; Anna Blume, 2002.

NEVES, Gervásio R. Territorialidade, desterritorialidade, novas territorialidades (algumas notas). In: SANTOS, Milton; SOUZA, Maria A. A.; SILVEIRA, Maria L., Território: Globalização e fragmentação. 5. ed., São Paulo: Hucitec; Anpur, 2002. 
KONG, Lily. Música popular nas análises geográficas. In: CORRÊA, Roberto L.; ROSENDHAL, Zeny (orgs.). Cinema, música e espaço. Rio de Janeiro: EdUERJ, 2009, p.129-175.

OLIVEIRA, Hélio C. M.; SILVA, Marcelo G.; NETO, Aristóteles T.; VLACH, Vânia R. F. A música como um recurso alternativo nas práticas educativas em Geografia: Algumas reflexões. Caminhos da Geografia, Instituto de Geografia/UFU, v. 8, n. 15, p. 73-81, jun. de 2005.

RAFFESTIN, Claude. Por uma Geografia do poder. São Paulo: Ática, 1993.

SACK, Robert. Human territoriality: Its theory and history. New York: Cambridge, 1986.

SANTOS, Milton; SILVEIRA, Maria. L. O Brasil: Território e sociedade no início do século XXI. 10 a. ed., São Paulo/Rio de Janeiro: Record, 2010.

SANTOS, Milton. O retorno do território. In: SANTOS, Milton; SOUZA, Maria A. A.; SILVEIRA, Maria L., Território: Globalização e fragmentação. 5. ed., São Paulo: Hucitec, Anpur, 2002, p. 11-14.

SANTOS, Milton. Por uma outra globalização: do pensamento único à consciência universal. Rio de Janeiro: Record, 2001.

SANTOS, Milton. A natureza do espaço: técnica e tempo, razão e emoção. São Paulo: Hucitec, 1996.

SOUZA, Marcelo L. O território: sobre espaço, poder, autonomia e desenvolvimento. In: CASTRO, Iná E., et. al (orgs.), Geografia: conceitos e temas. 2. ed. Rio de Janeiro: Bertrand, 1999, p.77-116.

SAQUET, Marcos. A. Abordagens e concepções de território. São Paulo: Expressão Popular, 2007.

SPOSITO, Eliseu. S. Geografia e filosofia: contribuições para o ensino do pensamento geográfico. São Paulo: Edunesp, 2004.

TURRA, Nécio. Enterrado vivo: identidade punk e território em Londrina. São Paulo: Edunesp, 2004.

\section{Anexo}

Quadro - Letras de músicas que remetem à questão territorial

\begin{tabular}{|l}
\hline $\begin{array}{l}\text { Saudosa Maloca } \\
\text { (Adoniran Barbosa) }\end{array}$ \\
\hline Si o senhor não "tá" lembrado \\
Dá licença de "contá" \\
Que aqui onde agora está \\
Esse “edifício arto" \\
Era uma casa véia \\
Um palacete assombradado \\
Foi aqui seu moço \\
Que eu, Mato Grosso e o Joca \\
Construímo nossa maloca \\
Mais, um dia \\
Nóis nem pode se alembrá \\
Veio os homi c'as ferramentas \\
O dono mandô derrubá \\
Peguemo todas nossas coisas \\
E fumos pro meio da rua \\
Aprecia a demolição
\end{tabular}




\section{Sobradinho}

(Sá e Guarabyra)

O homem chega e já desfaz a natureza

Tira a gente põe represa, diz que tudo vai mudar

O São Francisco lá prá cima da Bahia

Diz que dia menos dia vai subir bem devagar

E passo a passo vai cumprindo a profecia

Do beato que dizia que o sertão ia alagar

O sertão vai virar mar

Dá no coração

O medo que algum dia

O mar também vire sertão

Vai virar mar

Dá no coração

O medo que algum dia

O mar também vire sertão

Adeus Remanso, Casa Nova, Sento-sé

Adeus Pilão Arcado vem o rio te engolir
Debaixo d'água lá se vai a vida inteira

Por cima da cachoeira, o Gaiola vai subir

Vai ter barragem no salto do Sobradinho

E o povo vai se embora com medo de se afogar

O sertão vai virar mar

Dá no coração

O medo que algum dia

O mar também vire sertão

Vai virar mar

Dá no coração

$\mathrm{O}$ medo que algum dia

O mar também vire sertão

Remanso, casa nova, sento sé, pilão arcado, sobradinho (...)

Adeus, adeus

\section{Aluga-se}

(Raul Seixas e Cláudio Roberto)

A solução pro nosso povo

Eu vou dá

Negócio bom assim

Ninguém nunca viu

Tá tudo pronto aqui

É só vim pegar

A solução é alugar o Brasil!...

Nós não vamo paga nada

Nós não vamo paga nada

É tudo free!

Tá na hora agora é free

Vamo embora
Dá lugar pros gringo entrar

Esse imóvel tá prá alugar

Ah! Ah! Ah! Ah! Ah! Ah!...

Os estrangeiros

Eu sei que eles vão gostar

Tem o Atlântico

Tem vista pro mar

A Amazônia

É o jardim do quintal

E o dólar dele

Paga o nosso mingau... 


\begin{tabular}{|l|l|}
\hline \multicolumn{2}{|l|}{$\begin{array}{l}\text { Disneylândia } \\
\text { (Arnaldo Antunes e Paulo Miklos) }\end{array}$} \\
\hline Filho de imigrantes russos casado na Argentina & E produzem com matéria prima brasileira \\
Com uma pintora judia, & Para competir no mercado americano \\
Casou-se pela segunda vez & Literatura grega adaptada \\
Com uma princesa africana no México & Para crianças chinesas da comunidade européia. \\
Música hindú contrabandiada por ciganos & Relógios suiços falsificados no Paraguay \\
poloneses faz sucesso & Vendidos por camelôs no bairro mexicano de Los \\
No interior da Bolívia zebras africanas & Angeles. \\
E cangurus australianos no zoológico de Londres. & Turista francesa fotografada semi-nua com o \\
Múmias egípcias e artefatos íncas no museu de & namorado árabe \\
Nova York & Na baixada fluminense \\
Lanternas japonesas e chicletes americanos & Filmes italianos dublados em inglês \\
Nos bazares coreanos de São Paulo. & Com legendas em espanhol nos cinemas da \\
Imagens de um vulcão nas Filipinas & Turquia \\
Passam na rede de televisão em Moçambique & Pilhas americanas alimentam eletrodomésticos \\
Armênios naturalizados no Chile & ingleses na Nova Guiné \\
Procuram familiares na Etiópia, & Gasolina árabe alimenta automóveis americanos na \\
Casas pré-fabricadas canadenses & África do Sul. \\
Feitas com madeira colombiana & Pizza italiana alimenta italianos na Itália \\
Multinacionais japonesas & Crianças iraquianas fugidas da guerra \\
Instalam empresas em Hong-Kong & Não obtêm visto no consulado americano do Egito \\
& Para entrarem na Disneylândia \\
\hline
\end{tabular}

Recebido em 16/01/2014

Aceito para publicação em 11/08/2014 